TABLE I-Mean Pulmonary Function Values ( \pm S.D.) in 35 Asymptomatic Patients with FEV ${ }_{1}:$ FVC Ratios greater than $70 \%$

\begin{tabular}{|c|c|c|c|c|c|c|c|c|c|c|}
\hline & $\begin{array}{c}\text { Age } \\
\text { (Years) }\end{array}$ & $\underset{(\mathrm{cm})}{\text { Height }}$ & $\underset{(\mathbf{k g})}{\text { Weight }}$ & $\underset{\text { (1) }}{\mathrm{FEV}_{1}}$ & $\underset{(1)}{\text { FVC }}$ & $\underset{(1)}{\mathrm{TLC}}$ & $\underset{(1)}{\text { FRC }}$ & $\begin{array}{l}\text { RV } \\
(1)\end{array}$ & RV:TLC & $\underset{\underset{\left(\mathrm{mmol}^{-1}\right)}{\mathrm{D}_{\mathrm{L}} \mathrm{CO}}}{\mathrm{kPa}^{-1}}$ \\
\hline $\begin{array}{l}\text { Actual value } \\
\text { \% of predicted } \\
\text { normal }\end{array}$ & $28 \cdot 3 \pm 13 \cdot 8$ & $162 \cdot 5 \pm 10 \cdot 1$ & $61.9 \pm 11 \cdot 3$ & $\begin{array}{r}2.9 \pm 0.8 \\
93.1 \pm 17.5\end{array}$ & $\begin{array}{r}3.5 \pm 1.0 \\
103.6 \pm 17 \cdot 4\end{array}$ & $\begin{array}{r}5 \cdot 1 \pm 1.2 \\
95.5 \pm 14.8\end{array}$ & $\begin{array}{r}2 \cdot 8 \pm 0.8 \\
109.6 \pm 29 \cdot 3\end{array}$ & $\begin{array}{r}1.6 \pm 0.5 \\
118.2 \pm 45.0\end{array}$ & $\begin{array}{r}31 \cdot 2 \pm 7.9 \\
113.0 \pm 24 \cdot 6\end{array}$ & $\begin{array}{r}9 \cdot 2 \pm 2.5 \\
96.5 \pm 21 \cdot 6\end{array}$ \\
\hline
\end{tabular}

Conversion: SI to Traditional Units- $\mathrm{D}_{\mathrm{L}} \mathrm{co}: 1 \mathrm{mmol} \mathrm{min}^{-1} \mathrm{kPa}^{-1} \approx 3 \mathrm{ml} / \mathrm{min} / \mathrm{mm} \mathrm{Hg}$

TABLE II-Mean Arterial Blood Gas Values ( \pm S.D.) in 35 Asymptomatic Asthmatic Patients compared with Values Predicted from Regression Equations of Diament and Palmer (1969)

\begin{tabular}{l|c|c|c}
\hline & $\begin{array}{c}\mathrm{PaO}_{3} \\
(\mathrm{kPa})\end{array}$ & $\begin{array}{c}\mathrm{PaCO}_{2} \\
(\mathrm{kPa})\end{array}$ & $\mathrm{pH}$ \\
\hline $\begin{array}{c}\text { Actual value } \\
\text { Predicted value }\end{array}$ & $\begin{array}{c}11.1 \pm 1.3 \\
13.4 \pm 0.6\end{array}$ & $\begin{array}{c}4.8 \pm 0.5 \\
5.3 \pm 0.2\end{array}$ & $\mathbf{7 . 4 4} \pm 0.03$ \\
\hline
\end{tabular}

Conversion: SI to Traditional Units

Blood gases: $1 \mathrm{kPa} \approx 7.5 \mathrm{~mm} \mathrm{Hg}$

normal even when the $\mathrm{FEV}_{1}$ was reduced and there was marked lung hyperinflation (RV $156 \%$ of predicted normal). Mayfield et al. (1971) found a comparable degree of hypoxaemia, but their patients had $\mathrm{FEV}_{1}: \mathrm{FVC}$ ratios less than $70 \%$.

Thus asthmatic patients in remission may have significant degrees of arterial hypoxaemia and hypocapnia and lung hyperinflation even when their ventilatory function, as assessed by the $\mathrm{FEV}_{1}$ :FVC ratio, is normal. This is perhaps not surprising because it is becoming increasing clear that the pulmonary abnormalities of bronchial asthma-whether owing to obstruction of the small peripheral airways (less than $2 \mathrm{~mm}$ in diameter) or loss of elastic recoil in the surrounding lung parenchyma-are not always detected by the simpler spirometric tests, possibly because these tests reflect mainly changes in the calibre of the larger airways. Hence, the results of simple spirometric tests of lung function must be interpreted with care in asthmatic patients.

\section{References}

Cade, J. F., and Pain, M. C. F. (1973). Australian and New Zealand fournal of Medicine, 3, 545

Cotes, J. E. (1968). Lung function, 2nd edn., p. 384. Oxford, Blackwell. Diament, M. L., and Palmer, K. N. V. (1969). Thorax, 24, 126. Higgins, M. W., and Keller, J. B. (1973). American Review of Respiratory Disease, 108, 258

Levine, G., et al. (1970). The New England fournal of Medicine, 282, 1277. Mayfield, J. D., Paez, P. N., and Nicholson, D. P. (1971). Thorax, 26, 591. Palmer, K. N. V., and Kelman, G. R. (1973). American Review of Respirator Disease, 108, 940.

Teculescu, D., and Stanescu, D. (1970). Revue Roumaine de Medicine Interne,

Valabhji, P. (1968). Clinical Science, 34, 431.

\title{
Detection of Continuing Gluten Ingestion in Treated Coeliac Patients
}

\author{
P. G. BAKER， R. E. BARRY， A. E. READ
}

British Medical fournal, 1975, 1, 486-488

\section{Summary}

To assess the incidence and effects of continuing gluten ingestion in coeliac disease 51 adult coeliac patients were studied after four to 132 (mean 63) months on a prescribed gluten-free diet. Each patient completed a prospective dietary questionnaire, underwent a repeat jejunal biopsy, and gave serum for gluten antibody estimation.

Altogether $65 \%$ of patients were still ingesting gluten, often inadvertently. Direct questioning on dietary habits had failed to uncover most of this consumption. The gluten antibody test proved a useful screening test for detecting continuing gluten ingestion and patients with both persistent subtotal villous atrophy and gluten antibodies were almost certain to be taking large amounts $(\geqslant 2 \mathrm{~g} / \mathrm{day})$. The presence of persistent partial villous atrophy was found, however, to be an unreliable guide to gluten intake.

\footnotetext{
University Department of Medicine, Bristol Royal Infirmary, Bristol BS2 8HW

P. G. BAKER, M.B., CH.B., Research Fellow

R. E. BARRY, M.D., M.R.C.P., Registrar

A. E. READ, M.D., F.R.C.P., Professor of Medicine
}

\section{Introduction}

Since Dicke's original observation on the deleterious effect of wheat in patients with coeliac disease (Dicke, 1950) and the subsequent discovery that it was the gluten-containing fraction of wheat flour that had this effect (Dicke et al., 1953) the treatment of coeliac disease has been based on the strict exclusion of gluten from the diet. Though failure to respond clinically and morphologically to gluten withdrawal occurs in a few coeliac patients-the "steroid-dependent non-responders" (Althausen and Uyeyama, 1969)-persisting minor degrees of jejunal mucosa abnormality are commonly seen in adults who have been treated by a gluten-free diet for several years. These abnormalities are rarely seen in children with treated coeliac disease. Antibodies to gluten in the serum, stools, or duodenal juice (Berger 1958; Taylor et al., 1961; Heiner et al., 1962; Carswell and Ferguson, 1972) have been noted in some patients with coeliac disease despite several years' treatment with a gluten-free diet.

These observations could be explained on the basis of continuing gluten ingestion. This hypothesis is supported by work (Dissanayake et al., 1974) showing that many coeliac patients were not keeping to a strict gluten-free diet and that the degree of mucosal abnormality (both morphological and biochemical) was proportional to the amount of gluten being ingested. In our study we were concerned not only with determining the relationship between gluten ingestion and persisting small-bowel abnormalities but also with pinpointing the sources of gluten and the reasons for its continued ingestion. 
We also investigated a screening test to detect continuing ingestion of gluten based on the presence or absence of circulating antibodies to gluten

To ascertain how nationally typical our figures for the percentage of patients continuing to ingest gluten were we asked for similar information from colleagues at seven other centres in Britain prominent in the management of coeliac patients, and our diabetics department requested similar information from the dietitians at these centres.

\section{Methods}

Fifty-one patients with coeliac disease proved on biopsy who had been treated for four to 132 (mean 63) months by a gluten-free diet were studied. All were volunteers, the nature of the study having been carefully explained to them. Each patient received a dietary questionnaire, as illustrated, gave serum for gluten antibody estimation, and underwent a repeat jejunal biopsy. The questionnaire was prospective, and patients were asked to complete it over four weeks. An accompanying letter explained the reasons for the survey and gave advice on how it should be completed. All patients had a copy of the Coeliac Society Handbook of Gluten-free Foods 1972-3 (Colman, 1972).

\section{QUESTIONNAIRE ANALYSIS}

The gluten content of the various foodstuffs eaten by the patients taking part in the survey was established by either: using the Coeliac Society List of Gluten-free Foods 1972-3 (Colman, 1972) to see whether or not the foodstuff in question was listed as gluten free, examining the information on ingredients given on the label of the food, or direct communication with manufacturers.

The daily gluten of the average British adult is $7 \mathrm{~g}$ (Ministry of
Design of questionnaire.

Please tick appropriate boxes and columns:

Name:

Date:

No. of years on gluten-free diet:

I am on a normal diet

I keep to a completely gluten-free diet

I exclude as much as I can

Over the past year or since starting my gluten-free diet this year I have eaten the following:

Food Article Frequency of Eating

\begin{tabular}{llr}
\hline Manufacturer Type Remarks Daily & 2 or 3 \\
Times Weekly Monthly $3-6$ & Every \\
Weekly & Months
\end{tabular}

Agriculture Fisheries and Food figures for third quarter 1972). This is contained in three to four slices of ordinary white bread so that patients eating the equivalent of one or more slices of ordinary bread a day could be regarded as consuming at least $2 \mathrm{~g}$. On the basis of this reasoning patients fell into three groups: those ingesting no gluten; those ingesting small amounts ( $<2 \mathrm{~g} /$ day) of gluten, and those ingesting large amounts ( $\geqslant 2 \mathrm{~g} /$ day) of gluten.

MUCOSAL MORPHOLOGY

Jejunal biopsy specimens were obtained under fluoroscopic control

Data on Dietary Habits of 51 Coeliac Patients and Results of Immunological and Morphological Investigations

\begin{tabular}{|c|c|c|c|c|c|c|c|}
\hline $\begin{array}{l}\text { Case } \\
\text { No. }\end{array}$ & $\begin{array}{c}\text { Age } \\
\text { (Years) }\end{array}$ & Sex & $\begin{array}{l}\text { No. of Years } \\
\text { on Gluten- } \\
\text { free Diet }\end{array}$ & $\begin{array}{l}\text { "Do You Keep to } \\
\text { Completely } \\
\text { Gluten-free Diet ?" }\end{array}$ & $\begin{array}{c}\text { Serum } \\
\text { Gluten } \\
\text { Antibody } \\
\text { Titre }\end{array}$ & $\begin{array}{l}\text { Gluten } \\
\text { Intake }\end{array}$ & $\begin{array}{c}\text { Jejunal } \\
\text { Morphology }\end{array}$ \\
\hline $\begin{array}{r}1 \\
2 \\
3 \\
4 \\
5 \\
6 \\
7 \\
8 \\
9 \\
10 \\
11 \\
12 \\
13 \\
14 \\
15 \\
16 \\
17 \\
18 \\
19 \\
20 \\
21 \\
22 \\
23 \\
24 \\
25 \\
26 \\
27 \\
28 \\
29 \\
30 \\
31 \\
32 \\
33 \\
34 \\
35 \\
36 \\
37 \\
38 \\
39 \\
40 \\
41 \\
42 \\
43 \\
44 \\
45 \\
46 \\
47 \\
48 \\
49 \\
50 \\
51\end{array}$ & $\begin{array}{l}54 \\
28 \\
23 \\
60 \\
40 \\
69 \\
24 \\
33 \\
17 \\
26 \\
65 \\
49 \\
35 \\
56 \\
55 \\
48 \\
60 \\
43 \\
41 \\
49 \\
33 \\
60 \\
34 \\
47 \\
54 \\
63 \\
49 \\
34 \\
38 \\
55 \\
56 \\
14 \\
41 \\
53 \\
34 \\
21 \\
35 \\
34 \\
47 \\
41 \\
34 \\
81 \\
38 \\
36 \\
48 \\
31 \\
32 \\
17 \\
48 \\
68 \\
32\end{array}$ & 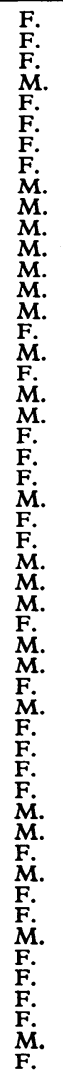 & $\begin{array}{c}3 \\
1 \cdot 5 \\
10 \\
2 \cdot 5 \\
4 \\
10 \\
5 \\
6 \\
0 \cdot 4 \\
11 \\
8 \\
6 \\
1 \cdot 5 \\
10 \\
5 \\
3 \\
4 \\
1 \cdot 5 \\
7 \\
0 \cdot 5 \\
11 \\
4 \\
2 \\
1 \\
6 \\
1 \cdot 5 \\
7 \\
1 \\
0 \cdot 5 \\
6 \\
5 \\
7 \\
6 \\
11 \\
7 \\
3 \\
5 \\
1 \\
3 \\
1 \\
5 \\
0 \cdot 4 \\
3 \\
1 \\
3 \\
10 \\
3 \\
4 \\
5 \\
0 \cdot 6 \\
1\end{array}$ & $\begin{array}{l}\text { Yes } \\
\text { No } \\
\text { No } \\
\text { Yes } \\
\text { Yes } \\
\text { No } \\
\text { Yes } \\
\text { Yes } \\
\text { Yes } \\
\text { Yes } \\
\text { Yes } \\
\text { Yes } \\
\text { Yes } \\
\text { Yes } \\
\text { Yes } \\
\text { Yes } \\
\text { Yes } \\
\text { Yes } \\
\text { Yes } \\
\text { Yes } \\
\text { Yes } \\
\text { Yes } \\
\text { Yes } \\
\text { No } \\
\text { Yes } \\
\text { Yes } \\
\text { Yes } \\
\text { Yes } \\
\text { Yes } \\
\text { Yes } \\
\text { Yes } \\
\text { Yes } \\
\text { Yes } \\
\text { Yes } \\
\text { Yes } \\
\text { Yes } \\
\text { Yes } \\
\text { Yes } \\
\text { Yes } \\
\text { Yes } \\
\text { Yes } \\
\text { Yes } \\
\text { Yes } \\
\text { Yes } \\
\text { Yes } \\
\text { Yes } \\
\text { Yes } \\
\text { Yes } \\
\text { No } \\
\text { Yes } \\
\text { Yes } \\
\end{array}$ & $\begin{array}{r}64 \\
16 \\
128 \\
4096 \\
64 \\
128 \\
0 \\
0 \\
32 \\
0 \\
128 \\
0 \\
0 \\
0 \\
16 \\
64 \\
0 \\
0 \\
0 \\
0 \\
0 \\
0 \\
0 \\
256 \\
0 \\
32 \\
0 \\
0 \\
0 \\
0 \\
0 \\
0 \\
0 \\
0 \\
32 \\
64 \\
32 \\
0 \\
0 \\
0 \\
128 \\
0 \\
16 \\
0 \\
0 \\
1028 \\
16 \\
32 \\
16 \\
0 \\
32\end{array}$ & $\begin{array}{l}\text { Small } \\
\text { Large } \\
\text { Large } \\
\text { Nil } \\
\text { Small } \\
\text { Large } \\
\text { Small } \\
\text { Nil } \\
\text { Large } \\
\text { Small } \\
\text { Small } \\
\text { Small } \\
\text { Nil } \\
\text { Nil } \\
\text { Small } \\
\text { Small } \\
\text { Nil } \\
\text { Nil } \\
\text { Nil } \\
\text { Small } \\
\text { Small } \\
\text { Small } \\
\text { Small } \\
\text { Large } \\
\text { Small } \\
\text { Nil } \\
\text { Nil } \\
\text { Nil } \\
\text { Nil } \\
\text { Small } \\
\text { Small } \\
\text { Nil } \\
\text { Nil } \\
\text { Small } \\
\text { Small } \\
\text { Small } \\
\text { Large } \\
\text { Small } \\
\text { Small } \\
\text { Nil } \\
\text { Large } \\
\text { Nil } \\
\text { Nil } \\
\text { Small } \\
\text { Nil } \\
\text { Large } \\
\text { Small } \\
\text { Small } \\
\text { Large } \\
\text { Nil } \\
\text { Small }\end{array}$ & $\begin{array}{l}\text { P.V.A. } \\
\text { S.V.A. } \\
\text { S.V.A. } \\
\text { S.V.A. } \\
\text { P.V.A. } \\
\text { S.V.A. } \\
\text { Normal } \\
\text { Normal } \\
\text { S.V.A. } \\
\text { Normal } \\
\text { P.V.A. } \\
\text { Normal } \\
\text { P.V.A. } \\
\text { P.V.A. } \\
\text { P.V.A. } \\
\text { P.V.A. } \\
\text { Normal } \\
\text { P.V.A. } \\
\text { P.V.A. } \\
\text { P.V.A. } \\
\text { Normal } \\
\text { Normal } \\
\text { Normal } \\
\text { S.V.A. } \\
\text { P.V.A. } \\
\text { P.V.A. } \\
\text { S.V.A. } \\
\text { P.V.A. } \\
\text { P.V.A. } \\
\text { P.V.A. } \\
\text { P.V.A. } \\
\text { Normal } \\
\text { Normal } \\
\text { Normal } \\
\text { P.V.A. } \\
\text { Normal } \\
\text { S.V.A. } \\
\text { P.V.A.. } \\
\text { P.V.A. } \\
\text { P.V.A. } \\
\text { S.V.A. } \\
\text { S.V.A. } \\
\text { P.V.A.A. } \\
\text { P.V.A. } \\
\text { Normal } \\
\text { S.V.A. } \\
\text { P..A.A. } \\
\text { P.V.A.A. } \\
\text { S.v.A.A. } \\
\text { P.v.A. }\end{array}$ \\
\hline
\end{tabular}


from the proximal jejunum 5- to $10-\mathrm{cm}$ distal to the ligament of Treitz, using a Crosby-Watson capsule. Specimens were examined under the dissecting microscope, and the villous pattern was classified as flat (mosaic or cobblestone), ridges and convolutions, broad leaves, or finger-like. These stereomicroscopic appearances were used as a cross-check on the histological grading, a flat mucosa being equivalent to subtotal villous atrophy, ridges and convolutions to partial villous atrophy, broad leaves to partial villous atrophy or normal, and finger-like always being associated with normal histological appearances. Specimens were fixed in $10 \%$ formol saline, embedded in paraffin wax, stained, and sectioned. The histological grading system was based on the results obtained by Madanagopalan et al. (1965) and Stewart et al. (1967). With a micrometer eyepiece the height of six villi was measured from the crypt-villous junction to the tip of the villous and compared with the total mucosal thickness as measured from the muscularis mocosae to the tip of the same six villi. The average result was then calculated. A subjective estimate of whether there was an excess of chronic inflammatory cells in the lamina propria or not was also made.

The grading criteria used were as follows: (a) normal, villous height $>350 \mu \mathrm{m}$. Villous height/total mucosal thickness $>0.65$. No excess of chronic inflammatory cells in the lamina propria; (b) partial villous atrophy, villous height $150-350 \mu \mathrm{m}$. Villous height/total mucosal thickness $=0.30-0.65$. Excess of chronic inflammatory cells present in the lamina propria; $(c)$ subtotal villous atrophy, villous height $<150 \mu \mathrm{m}$. Villous height/total mucosal thickness $<0.30$. Excess of chronic inflammatory cells present in the lamina propria.

Serum gluten antibodies were measured using the tanned erythrocyte test (Boyden, 1951). Tanned group-O human red cells were coated with Frazer's fraction III (Frazer et al., 1959), and tests were carried out using Cooke microtiter apparatus.

\section{Results}

Of the 51 patients studied $33(65 \%)$ were continuing to ingest gluten. Nine were ingesting large amounts and 24 small amounts. Serum gluten antibodies were detected in all nine patients with a large gluten intake, in 10 of the 24 taking small amounts of gluten, and in three of the 18 patients who kept to a completely gluten-free diet. Of the nine patients ingesting large amounts of gluten, four said that they were keeping to a completely gluten-free diet (see table). As the main sources of gluten for patients in this group were bread, biscuits, cakes, pies, and fish and chips, however, it was unlikely that continuing gluten ingestion was accidental.

All 24 patients in the small gluten-intake group stated that they kept to a completely gluten-free diet. The most common gluten-containing foodstuffs eaten by this group of patients were confectionery, mustards, sauces, gravies, sausages, faggots, soups, flavoured crisps, and communion wafers. Direct questioning at a later date showed that these patients were almost invariably unaware of the fact that they were still ingesting gluten.

Thirty-eight patients (75\%) still had an abnormal jejunal mucosa, 13 having subtotal villous atrophy, and 25 having partial villous atrophy. Four of the patients with subtotal villous atrophy did not seem to be ingesting any gluten, but the other nine all had a large intake. Nine of the patients with partial villous atrophy had no gluten intake and the remaining 16 had a small intake.

There was a highly significant correlation $(P<0.001)$ between a large gluten intake and persistent subtotal villous atrophy, and an even greater correlation when both subtotal villous atrophy and serum gluten antibodies were present. (see table). There was also a significant correlation $(P<0.05)$ between the presence of gluten antibodies and continuing gluten ingestion.

\section{Discussion}

Subtotal villous atrophy persisting despite a strict gluten-free diet was not associated with the presence of gluten antibodies, and persistent partial villous atrophy did not seem to correlate with either gluten ingestion or gluten antibodies. This latter finding contrasts with that of Dissanayake et al. (1974), who reported that the degree of persisting mucosal abnormality was proportional to the amount of gluten being ingested. They used different criteria for grading both the mucosa and gluten ingestion, however, so that a direct comparison was precluded. There was no correlation between the age or sex of the patients and persistence of mucosal abnormalities, this being in accord with the findings of Dissanayake et al.

The information obtained from the seven other British centres, all of which dealt with many coeliac patients, indicated disparate views in many cases between the physicians and dietitians concerning what was being done to maintain the patients on their diets. Direct questioning by a physician, dietitian, or specially trained person was the only method reported for assessing dietary habits, and the dietitians rarely saw coeliac patients after initially instructing them about their gluten-free diets.

Estimates of the percentage of patients adhering to a strict gluten-free diet ranged from $20 \%$ to $100 \%$, with "not known" being the commonest answer. "Not known" was also the manufacturers' general response to questions about the gluten content of their products. In two cases the manufacturers could not give a definite answer until they had carefully studied their ingredients and processes with gluten particularly in mind. Such a situation is further complicated by frequent sudden and unannounced alterations in product ingredients and manufacture, which might introduce gluten into a previously glutenfree foodstuff, which is listed as such.

As the attempt to label gluten-free foods by means of a special symbol has gained little acceptance, it is important that manufacturers should be able to state on the label whether or not gluten is an ingredient of that food.

\section{Conclusion}

Apparently many treated coeliac patients continue to ingest gluten despite dietary instruction and the benefits of membership of the Coeliac Society. As the ingestion is often inadvertent and remains undetected by direct questioning an accurate assessment of intake may be conveniently established by the use of a prospective dietary questionnaire. The detection of gluten antibodies also provides a useful indication of those patients who continue to ingest gluten.

We recommend, in addition to the use of a dietary questionnaire and estimation of gluten antibodies, that a regular close liaison should be established between dietitian and patient. At our coeliac out-patient clinic there is always a dietitian in attendance to check on dietary control and deal with any related problems.

\section{References}

Althausen, T. L., and Uyeyama, K. (1969). Gastroenterologic Medicine, ed. M. Paulson, p. 840. Philadelphia, Lea and Febinger.

Berger, E. (1958). Bibliotheca Pediatrica no. 67.

Boyden, S. V. (1951). Fournal of Experimental Medicine, 93, 107.

Carswell, F., and Ferguson, A. (1972). Archives of Disease in Childhood, 47, 594.

Colman, J. (1972). Coeliac Society List of Gluten-free Foods 1972-3. Bedford, Sidney Press.

Dicke, W. K. (1950). M.D. Thesis, Utrecht.

Dicke, W. K., Weijers, H. A., and van de Kamer, J. H. (1953). Acta Pediatrica Scandanavica, 42, 34.

Dissanayake, A. S., Truelove, S. C., and Whitehead, R. (1974). Quarterly fournal of Medicine, 43, 161.

Frazer, A. C., et al. (1959). Lancet, 2, 252.

Heiner, D. C., et al. (1962). Fournal of Pediatrics, 61, 813.

Madanagopalan, N., Shiner, M., and Rowe, B. (1965). American fournal of Medicine, 38, 42.

Stewart, J. S., et al. (1967). Quarterly Fournal of Medicine, 36, 425.

Taylor, K. B., Thomson, D. L., Truelove, S. C., and Wright, R. (1961) British Medical fournal ii, p 1727. 